\title{
An analysis of learning interactions in a cross-border network for sustainable urban neighbourhood development
}

Citation for published version (APA):

Valkering, P. J., Beumer, C., de Kraker, J., \& Ruelle, C. (2013). An analysis of learning interactions in a cross-border network for sustainable urban neighbourhood development. Journal of Cleaner Production, 49, 85-94. https://doi.org/10.1016/j.jclepro.2012.09.010

Document status and date:

Published: 01/06/2013

DOI:

10.1016/j.jclepro.2012.09.010

Document Version:

Publisher's PDF, also known as Version of record

\section{Document license:}

Taverne

Please check the document version of this publication:

- A submitted manuscript is the version of the article upon submission and before peer-review. There can be important differences between the submitted version and the official published version of record.

People interested in the research are advised to contact the author for the final version of the publication, or visit the DOI to the publisher's website.

- The final author version and the galley proof are versions of the publication after peer review.

- The final published version features the final layout of the paper including the volume, issue and page numbers.

Link to publication

\footnotetext{
General rights rights.

- You may freely distribute the URL identifying the publication in the public portal. please follow below link for the End User Agreement:

www.umlib.nl/taverne-license

Take down policy

If you believe that this document breaches copyright please contact us at:

repository@maastrichtuniversity.nl

providing details and we will investigate your claim.
}

Copyright and moral rights for the publications made accessible in the public portal are retained by the authors and/or other copyright owners and it is a condition of accessing publications that users recognise and abide by the legal requirements associated with these

- Users may download and print one copy of any publication from the public portal for the purpose of private study or research.

- You may not further distribute the material or use it for any profit-making activity or commercial gain

If the publication is distributed under the terms of Article $25 \mathrm{fa}$ of the Dutch Copyright Act, indicated by the "Taverne" license above, 


\title{
An analysis of learning interactions in a cross-border network for sustainable urban neighbourhood development
}

\author{
Pieter Valkering ${ }^{\mathrm{a}, \mathrm{b}, *}$, Carijn Beumer ${ }^{\mathrm{a}}$, Joop de Kraker $^{\mathrm{b}}$, Christine Ruelle ${ }^{\mathrm{c}}$ \\ a ICIS, Maastricht University, Maastricht, The Netherlands \\ ${ }^{\mathrm{b}}$ School of Science, Open Universiteit, Heerlen, The Netherlands \\ ${ }^{c}$ LEMA, University of Liège, Liège, Belgium
}

\section{A R T I C L E I N F O}

\section{Article history:}

Received 13 October 2011

Received in revised form 17 August 2012

Accepted 11 September 2012

Available online 16 September 2012

\section{Keywords:}

Sustainable development

Urban development

Learning networks

Joint learning

Knowledge boundaries

\begin{abstract}
A B S T R A C T
Learning networks have the potential to support joint learning and collective innovation processes needed for sustainable urban development. However, systematic analyses of joint learning processes in such networks are often lacking. In this paper, the Interreg project SUN (Sustainable Urban Neighbourhoods) is taken as a case study to analyse learning interactions in a regional network for sustainable urban neighbourhood development in the Euregio Meuse-Rhine. The SUN project provides concerted public and private action, focussing on community engagement, cross-border cooperation, and collective innovation. In this context, joint learning implies the exchange and co-production of knowledge among a diverse group of actors. We first describe the learning network of SUN in terms of the actors involved, the learning activities and tools applied, and the types of knowledge exchanged and co-produced (technical, attitudinal, innovative). These features are further used to characterize a set of typical learning interactions that generated learning across four main knowledge boundaries (territorial, rolebased, sectoral, and project boundaries). From this analysis, we identify main factors supporting the joint learning process, and discuss the general applicability and added value of the developed analytical framework.
\end{abstract}

(c) 2012 Elsevier Ltd. All rights reserved.

\section{Introduction}

Learning networks have the potential to support collective innovations needed for sustainable development at the regional level (Barton and Dlouhá, 2011). Such learning networks typically involve local authorities, knowledge institutes, businesses, NGOs and other stakeholders exchanging and co-producing knowledge on themes like agroforestry (Cardoso et al., 2001), energy efficiency (Jochem and Gruber, 2007), greener production and ecosystem management (Manring, 2007; Manring and Moore, 2006) and environmental management at the municipal level (Von Malmborg, 2007). Similar networks exist and were analysed within the scope of social learning and water management (PahlWostl et al., 2007), social learning and city planning (Holden, 2008), and agricultural transitions (Veldkamp et al., 2009). These networks share a focus on what we refer to as 'joint learning': the exchange and co-production of knowledge across disciplinary, territorial and other boundaries, as a way to support collective innovation processes.

\footnotetext{
* Corresponding author.

E-mail address: p.valkering@maastrichtuniversity.nl (P. Valkering).
}

Although joint learning is considered essential to support collective innovations for sustainable development, systematic analyses of learning processes in regional networks are often lacking. Armitage et al. (2008), for example, describe this as a learning paradox in adaptive co-management, arguing that despite widespread support for learning as a normative goal and process, "careful examination of the factors that determine if, who, how, when and what type of learning actually occurs" is often lacking. Holden (2008) concludes that "while often cited as part of the desired outcomes of planning and policy processes, social learning is rarely investigated from a process-based perspective able to reveal how and why it occurs to different degrees in different contexts." As a consequence, it is still largely unclear how effective learning networks for regional sustainable development are and how such networks can be best supported in order to optimize their learning effects.

In this paper, the ongoing Interreg project SUN ${ }^{1}$ (Sustainable Urban Neighbourhoods) is taken as a case study to address joint learning in a regional network for sustainable urban neighbourhood development in the Euregio Meuse-Rhine. The project falls

\footnotetext{
1 http://www.sun-euregio.eu (accessed August 2012).
} 
under the European Territorial Co-operation objective on crossborder cooperation, fostering knowledge exchange and cooperation along internal European borders ${ }^{2}$. The project engages Euregional academics, city practitioners, local stakeholders, non-profit organizations (NPOs), entrepreneurs and other professionals to implement concrete actions in seven pilot neighbourhoods on various sustainability themes (energy, greenery, economy, social cohesion). In this context, joint learning entails a broad palette from the exchange of technical knowledge on housing insulation, to developing a shared understanding of what a sustainable urban neighbourhood is, and collectively experimenting with promising, innovative practices.

The diversity of SUN project partners from different Euregional territories is expected to contribute to a rich joint learning process. Yet, the same diversity may create knowledge boundaries (Carlile, 2002) that need to be 'crossed' in order for joint learning really to occur. This raises a number of main questions: Through which project activities does joint learning actually occur? To what extent are knowledge boundaries effectively crossed? How can such boundary crossing best be facilitated? To address those questions, we provide an analysis of learning interactions in the SUN project. We do so by carefully examining three recent years of project activities, highlighting the activities through which learning interactions were generated, the actors involved, the type of knowledge exchanged and co-produced, and the knowledge boundaries that were crossed. We thus focus on portraying the context the SUN project as a learning network provides, and the way this context may support joint learning processes.

The paper is organised as follows. We first draw on the theoretical background of regional learning networks for sustainable development to clarify relevant terms (learning network, joint learning, learning interaction, knowledge boundary). Second, we describe the SUN project as a learning network, describing its members, the various activities and tools that supported learning, and the types of knowledge exchanged and co-produced. Third, we characterise a set of typical learning interactions in the SUN project that facilitated knowledge exchange and co-production across four main knowledge boundaries (territorial, role-based, sectoral, and project boundaries). From this analysis, we identify main factors supporting the joint learning process, and discuss the general applicability and added value of the analytical framework we developed for analysing joint learning in regional learning networks for sustainable development.

\section{Regional learning networks for sustainable development}

\subsection{Learning networks}

A learning network (LN) (Bessant and Tsekouras, 2001; Downes, 2007) is a network of actors that facilitates learning. Actors may include individuals and organisations, and the interactions among them may be facilitated, for example, through face-to-face meetings, web-based information exchange, and undertaking collaborative activities. The concept might be characterised as learning 'bottom-up', highlighting that learning occurs in communities, focussing on knowledge creation rather than consumption, and emphasising the decentralisation of content and control (Downes, 2007). When carefully designed, LNs have great potential to improve processes of knowledge acquisition and capacity building (Bessant and Tsekouras, 2001). They are of specific relevance in the context of sustainable development that generally requires

\footnotetext{
2 httpc://ec.europa.eu/regional_policy/cooperate/cooperation/index_en.cfm (accessed August 2012).
}

enhanced engagement between business, government and civil society. Networks may fulfil that requirement and create the ground for innovation through knowledge exchange and development (Roome, 2001).

A specific class of LNs is devoted to supporting sustainable development at the regional level. Von Malmborg (2007) highlights the increasing role of such regional actor-networks, involving both public authorities and the private sector, for collective innovation for sustainable development. Other examples of regional LNs for sustainable development can be found in the fields of social learning (Pahl-Wostl et al., 2007), systems of innovation (Cooke et al., 1997; Edquist, 1997; Lundvall, 1992; Schartinger et al., 2002), and communities of practice (Wenger, 1998). The character of such regional LNs may differ, including intra- or inter-regional networks, constituted of homogeneous or heterogeneous group members, and being formal or informal in nature (De Kraker et al., 2013).

\subsection{Joint learning}

We define joint learning in such networks as the exchange and co-production of knowledge among a generally diverse group of societal actors, as a way to support collective innovation processes. We thereby interpret the term 'knowledge' broadly to entail all the relevant objects of learning, including information, data, views, perceptions, values, norms, and technical and social-relational skills. The 'exchange of knowledge' thereby refers to the process of exchanging 'established' knowledge between actors, while the 'co-production of knowledge' refers to the joint development of ('new') knowledge among an actor group. Learning outcomes of joint learning thus typically pertain to two levels: individual- and group-level (see also De Kraker et al., 2013). Moreover, we use the term 'learning interaction' in our analysis to denote key types of interactions between members of the LN through which knowledge is exchanged or co-produced.

To describe joint learning processes, scholars often use four components (Bennett and Howlett, 1992; Van de Kerkhof and Wieczorek, 2005): the subjects of learning (who learns?), the process of learning (learns how?), the objects of learning (learns what?), and the results of learning (to what effect?). In our case, the subjects of learning refer to the members of the SUN learning network as described in Section 3.2. The process of learning refers to the concrete activities and supporting tools through which learning takes place (see Section 3.3). The objects of learning refer to the type of knowledge exchanged and co-produced (see Section 3.4). The results of learning refer to the concrete actions taken at the neighbourhood level and their implications for sustainable development. A full description of those results, however, is beyond the scope of this article. We limit our analysis to the first three components.

Concerning the objects of learning, the literature distinguishes different learning types. A main distinction is the one between 'single-loop' and 'double-loop' learning. The first-also labelled 'instrumental', 'first order', 'lower order', or 'cognitive' learning-concerns the acquisition of technical ('how-to') knowledge; the second-also labelled 'policy', 'second-order', 'higher order', or 'normative' learning-is a more reflexive type of learning involving changes in the underlying normative frame, e.g. changes in beliefs, values, objectives and problem perceptions (Haug et al., 2011; Van de Kerkhof and Wieczorek, 2005). Moreover, in regional LNs for sustainable development, learning is often embedded in practice. This implies relational learning outcomes, including the acquisition of technical and social-relational skills, and the group capacity to implement joint actions (Craps, 2003; Haug et al., 2011). 


\subsection{Knowledge boundaries}

Joint learning processes are expected to benefit from a broad spectrum of actors involved, each contributing different types of knowledge to the learning process (Downes, 2007). Such diversity, however, does not guarantee a successful learning process, as knowledge may remain within isolated knowledge domains. The 'community of practice' literature has shown how knowledge is structured by the types of problems being faced within a practice. Carlile (2002), for instance, describes knowledge as being localized around particular problems faced in a given practice, embedded in practice (tacit knowledge accumulated by individuals engaged in a given practice is hard to capture and transfer), and finally invested in practice (individuals are attached to the knowledge developed within a practice and usually not inclined to reconsider it and to develop new ways of thinking or dealing with problems). These three characteristics of knowledge have significant positive benefits within a practice, but lead to the specialization of knowledge, which becomes problematic when working across practices.

Such knowledge specialization may thus lead to what is known as a 'knowledge boundary'. Knowledge boundaries may arise between science, policy and society, between academic disciplines, government departments, companies' internal functions, and between actor groups with different language and cultural background (Carlile, 2002; Hegger et al., 2012; Wenger, 1998). Carlile $(2002,2004)$ has described the different nature and complexity of boundary types, distinguishing syntactic boundaries (that result from knowledge differences in terms of level or specialization), semantic boundaries (arising from different worldview and understanding of issues) and pragmatic boundaries (arising from differences in interests). In effective LNs, such knowledge boundaries need to be 'crossed'. In this regard, the term 'boundary object' (Carlile, 2002; Star and Griesemer, 1989) denotes artefacts that support learning across boundaries by providing a common reference point for communities within different knowledge domains (see also Oldenhuizing et al., 2013).

\section{The SUN project as a learning network}

\subsection{General characteristics}

The SUN project (Sustainable Urban Neighbourhoods) aims to stimulate the sustainable development of seven formerly industrial neighbourhoods clustered in the European cross-border region called Euregio Meuse-Rhine (EMR) that covers parts of Belgium, Germany and the Netherlands (see Fig. 1). The project runs from 2009 to 2012 and is part of the Interreg IVA programme on crossborder cooperation, co-financed by European Regional Development Funds and the different regional governing bodies constituting the EMR. The SUN project is constructed as a transdisciplinary action research project, engaging Euregional academics, city practitioners, local stakeholders, non-profit organisations (NPOs), entrepreneurs and other professionals. It places emphasis on the coordination of public and private action to effectively contribute to sustainable development of neighbourhoods, to community engagement, and to building networks to support collective innovation.

The project is structured around four thematic actions carried out in a total of seven different neighbourhoods. Neighbourhoods originate from five distinct areas of the Euregio Meuse-Rhine (see Fig. 1) that typically differ in terms of official language, culture, and institutional context. The participating neighbourhoods share a similar history of a flourishing industrial past and more recently a closure of many of the old industries, causing economic decline, social problems, decreasing quality of the physical environment,

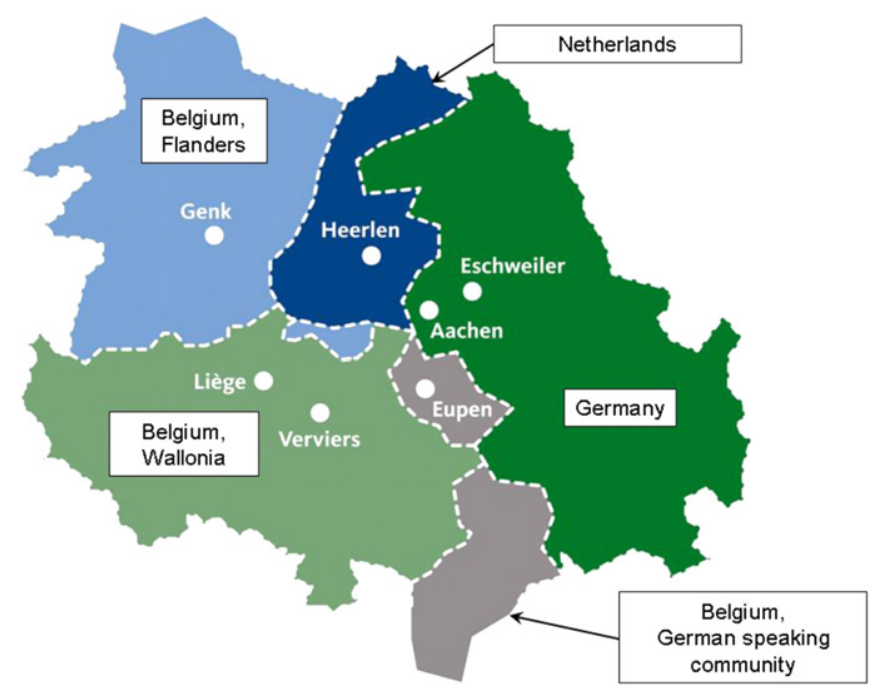

Fig. 1. Overview of the SUN Project area. The seven SUN case study neighbourhoods are located in Aachen (Aachen-Ost), Eschweiler (Eschweiler-Ost), Eupen (Unterstadt), Genk (Noord-west), Heerlen (MSP), Liège (St-Leonard), and Verviers (Hodimont) spread out over five distinct areas of the Euregio Meuse-Rhine (Germany, Netherlands, and Flanders, Wallonia and the German speaking community in Belgium).

and diminishing housing quality (Baeten et al., 1998; Dewulf, 2003; Fraser and Marechal, 2003; Heerlen, 2008; Pasmans and Voorburg, 2005). The project motto 'Enhance your neighbourhood!' reflects that such negative trends are to be reversed. To this end, collaborative actions are developed under the thematic actions Economy (to facilitate the reintegration or creation of compatible economic activities), Greenery (to develop neighbourhood's green infrastructure), Energy (to improve the energy efficiency of neighbourhood buildings, stimulate energy innovation, and create awareness about energy use), and Community (to facilitate new social connections within and between neighbourhoods and create a sense of social cohesion amongst the community members). The project thus constitutes a complex grid of action-neighbourhood combinations, allowing for joint learning within neighbourhoods, between neighbourhoods, and between action related themes (see Fig. 2).

The SUN project constitutes a learning network (SUN-LN) of collaborating actors aiming at innovation, amongst others through knowledge sharing and developing innovative practices. The network is quite heterogeneous, including representatives from municipalities, NPOs, academics, and individual citizens and entrepreneurs, with different backgrounds, expertise, and Euregional nationalities. The network can be considered intraregional-considering the Euregio as a single region-but can also be considered inter-regional when highlighting the differences between the various national territories. The structure of the network is initially formal, with participants generally representing organisations engaged through activities and tools set-up by the SUN project-team. On the longer term, however, the SUN project aims to evolve into an informal network in which knowledge exchange and innovation occurs in a more self-organised and autonomous way.

\subsection{Members of the learning network}

The SUN project constitutes a complex network of directly and indirectly involved actors, each with specific interests, means and roles in the project. Three main groups of actors can be discerned, here visualised as three concentric circles.

- The inner-circle is formed by the SUN project partners, communicating regularly to coordinate, plan, and evaluate 


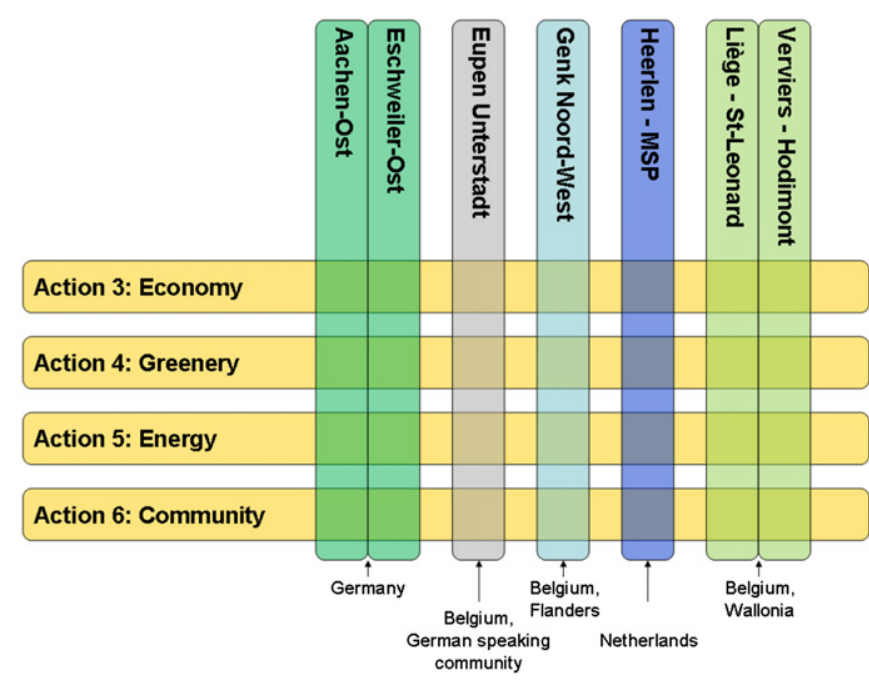

Fig. 2. The SUN project structure involves four main thematic actions being applied in seven different neighbourhoods. The neighbourhoods belong to five distinct areas of the Euregio Meuse-Rhine (Germany, Netherlands, and Flanders, Wallonia and the German speaking community in Belgium). Neighbourhoods belonging to the same area are relatively close in terms of language, culture, and institutional context. For most combinations of neighbourhoods and thematic actions neighbourhood activities have been set-up.

various project activities. Partners include 'Practitioners' (city workers, managing and/or carrying out projects on the neighbourhood level), 'NPOs' (non-profit organisations with expertise on, amongst others, sustainable building and community development), and 'Academics' (universities from Liège, Aachen, Hasselt, and Maastricht). Within their shared ambition to support sustainable urban neighbourhood development, their specific aims differ. Typically, academics aim to develop scientific knowledge and publish scientific papers, practitioners aim to achieve concrete targets in their neighbourhood and develop more efficient practices, and NPOs aim to develop their expertise and position as key player in the field.

- The second circle covers actors that are directly involved in various SUN activities, here referred to as the 'direct beneficiaries' of the project. First, such actors include various 'Local stakeholders': individual residents, local entrepreneurs, local associations, schools and other stakeholders within the SUN neighbourhoods. Their stake in the project concerns the implementation of the various core actions of SUN, in which they are directly involved, and from which they may directly benefit. Second, these include 'Euregional professionals', different from the project partners, from cities, provinces, NGOs and businesses in the Euregio working on specific sustainability themes. Their stake concerns primarily the development of their expertise and professional networks.

- The outer circle covers the 'indirect beneficiaries'. The latter include various interested parties (academics, practitioners, experts, citizens, policy-makers) in other regions, cities, and neighbourhoods, here referred to as the 'outside world'. They may benefit from knowledge development and dissemination in the SUN project. Conversely, the SUN project may benefit from exogenous experiences, for example by learning from innovative practices applied elsewhere.

\subsection{Activities and tools supporting joint learning}

Joint learning among the members of the SUN-LN is supported by several main activities and tools:
Project coordination: This includes regular project meetings, phone calls and email exchanges amongst project partners for planning, organizing and evaluating the various project activities.

Benchmarking activities: The project partners, mainly the academics and to a lesser extent the city practitioners and NPOs, look for interesting practices or policies developed in other cities in order to inspire the SUN partners. The inspiring practices are identified through literature review, web searches and by consulting the partners' networks. Academics summarize the most interesting sources of inspiration through 'case study' reports.

Neighbourhood activities: The implementation of the SUN actions in the neighbourhoods is co-managed by the SUN partners and involves active participation of local citizens. Neighbourhood activities include awareness raising activities, information sessions, training sessions, collective micro-projects and local events related to specific SUN actions.

Thematic meetings: SUN partners involved in each specific SUN action (Economy, Greenery, Energy or Community) meet on a regular basis to report on the implementation of their action in the various neighbourhoods, and exchange insights and good practices related to their theme.

SUN events: Five main SUN events have been planned along the project's duration; four being dedicated to sharing knowledge on each of the project's actions (Economy, Greenery, Energy, Community); one being the project's closing event, communicating the main lessons learnt. SUN events engage a broad audience, including the project partners, Euregional professionals, local stakeholders and the 'outside' world. SUN events are also used to communicate innovative practices applied elsewhere by inviting external speakers.

Site visits: General site visits are made to each SUN neighbourhood, where project partners receive information about the visited area, its history, evolution and management. In addition, various site visits are organised where SUN project partners and the local professionals ('outside world') exchange insights about innovative practices in place elsewhere that could be transferred to the context of SUN.

Community exchanges: Seven inter-neighbourhood exchanges are planned during the project. These activities take place in each neighbourhood, for instance at the occasion of a local festival. They typically involve guided tours, either to a well-known site in the neighbourhood, or to a micro-project realised through SUN. Inhabitants and other local stakeholders from all the SUN neighbourhoods are invited to participate, allowing for informal discussion and exchange.

Evaluation and monitoring: During the second part of the project, an evaluation of the SUN actions will take place in the participating neighbourhoods to assess which factors may contribute to sustainable development at the neighbourhood level. To initiate this process, a first attempt was made to develop a shared vision of what a Sustainable Urban Neighbourhood means to the various project partners (Beumer et al., 2010). This exercise was conducted by the academic partners and city practitioners, but will also involve NPOs, and local stakeholders in later stages of the project.

SUN website (public and member area): The public area of the SUN website ${ }^{1}$ is intended to keep a broad public informed about what is going on in the SUN project. It includes a description of the SUN project, the various actions and participating neighbourhoods. Also, it includes news items and an agenda to keep visitors up-todate on ongoing SUN activities. The public area is maintained in four different languages French, German, Dutch and English. The member area of the website is a place where project partners can find and exchange documents (archive function), discuss specific topics (forum function) and plan or announce an event (agenda function). 
Learn4SUN portal: In addition to the SUN website, an $\mathrm{Elgg}^{3}$ based prototype learning platform ${ }^{4}$ was designed to facilitate knowledge exchange (De Kraker et al., 2013). In the testing phase, this portal was used notably by the academics to facilitate their collaborative work. Also, it is intended as a platform to share knowledge on innovative practices.

Informal exchanges: Informal exchanges, finally, are all the spontaneous discussions occurring between any two or more LN members, through phone calls, emails or face-to-face meetings aimed at solving specific problems, or disseminating or obtaining specific information. These exchanges may generate informal learning, in this context defined as the totality of learning processes that are not organised, and generally occur without explicit learning objectives (Colardyn and Bjornavold, 2004).

\subsection{Objects of learning}

The types of knowledge exchanged and co-produced through the above activities and tools vary strongly in nature. Drawing from previous learning classifications (e.g. Craps, 2003; Haug et al., 2011; Van de Kerkhof and Wieczorek, 2005), we distinguish three main categories that are of specific relevance for the SUN-LN (see Table 1 for an overview):

- Technical: This covers the exchange of knowledge on established techniques and procedures (including scientific knowledge). The corresponding type of learning can be characterised as 'single-loop' learning that may result in individual-level outcomes. In the SUN project, this includes, for example, the exchange of knowledge on insulation techniques, rules and legal procedures to start up a business, administrative procedures to apply for subsidies for solar panels, and established methods for urban monitoring.

- Attitudinal: This covers the exchange and co-production of perceptions, norms, and values. The corresponding type of learning can be characterized as 'double-loop' that may result in both individual-level, as well as group-level outcomes. In the SUN project, this includes, for example, increasing awareness about energy use by monitoring energy consumption (individual-level outcome), and developing a common understanding of what is meant with a sustainable urban neighbourhood through envisioning exercises (group-level outcome).

- Innovative practices: This covers the exchange of knowledge about innovative practices and the co-production of new knowledge about those practices by collectively adapting and applying them in the SUN project. The corresponding type of learning can be characterized as 'double-loop' in light of the reflection on current and possible new practices it involves. Expected learning outcomes also include relational aspects (e.g. increased trust, increased ability to cooperate) (Haug et al., 2011) resulting from the collective effort of applying innovative practices in the various neighbourhoods. Learning outcomes thus potentially apply both to the individual and group level. In the context of SUN, innovative practices relate mainly to management-rather than technical-issues. They cover, for example, experimentation with new ways to stimulate energy renovation of private dwellings in a specific neighbourhood, experimenting with a new type of collaborative research action, and learning how to apply the notion of sustainable development in managing urban neighbourhoods.

\footnotetext{
${ }^{3}$ http://elgg.org.

4 http://www.learn4sun.eu.
}

Table 1

Three main categories of objects of learning of specific relevance for the SUN learning network, specified in terms of the content of learning, corresponding learning types (single loop, double loop, relational) and level of the expected learning outcomes (individual, group).

\begin{tabular}{|c|c|c|c|}
\hline & Technical & Attitudinal & Innovative practices \\
\hline $\begin{array}{l}\text { Content } \\
\text { of learning }\end{array}$ & $\begin{array}{l}\text { Established } \\
\text { techniques } \\
\text { and procedures }\end{array}$ & $\begin{array}{l}\text { Perceptions, } \\
\text { norms, } \\
\text { and values }\end{array}$ & $\begin{array}{l}\text { Innovative } \\
\text { management } \\
\text { practices }\end{array}$ \\
\hline $\begin{array}{l}\text { Corresponding } \\
\text { learning types }\end{array}$ & Single loop & Double loop & $\begin{array}{l}\text { Double loop } \\
\text { and relational }\end{array}$ \\
\hline $\begin{array}{l}\text { Level of learning } \\
\text { outcome }\end{array}$ & Individual & $\begin{array}{l}\text { Individual } \\
\text { and group }\end{array}$ & $\begin{array}{l}\text { Individual } \\
\text { and group }\end{array}$ \\
\hline
\end{tabular}

\section{Learning across boundaries: observations from the SUN project}

Having characterised the SUN project as a LN, we proceed with a more detailed overview of learning interactions that occurred across different types of knowledge boundaries. Without aiming to provide a full analysis of all boundary types, we highlight four main knowledge boundaries that emerge from the nature of the project:

- Territorial boundaries between actors from different parts of the Euregio. These correspond to knowledge boundaries between the five different regions that form the Euregio (see Fig. 2). These boundaries originate typically from differences in language, culture and institutional context. Crossing these boundaries constitutes a main target of the Interreg programme, which aims at strengthening cross-border cooperation.

- Role-based boundaries between actors with different societal roles, e.g., between academics, practitioners, NPOs, local stakeholders and Euregional professionals (see Section 3.2). These boundaries originate typically from differences in interests, means and roles in the SUN project and more generally in society.

- Sectoral boundaries between actors operating within the different thematic actions (see Fig. 2). These boundaries originate typically from differences in professional specialisations and expertise in relation to the themes of energy, economy, greening, and social cohesion.

- Project boundaries between actors within and outside the SUN project. These correspond to knowledge boundaries between project partners, direct beneficiaries and indirect beneficiaries (see Fig. 3). These boundaries originate typically from a difference in rationale for participating in SUN project activities.

Across each of these boundaries, various forms of learning interactions occurred, often involving multiple boundaries at the same time $e^{5}$. To provide an overview, we present a set of typical learning interactions as observed during the first 3 years of the SUN project in Table 2. This set was established through brainstorming between the academic researchers involved as project partners in the day-to-day monitoring of the SUN project. Each identified type of learning interaction-numbered $1-9$-is characterized according to the boundary (or boundaries) it relates to, the actors involved (who?), the kind of project related activities and tools which supported learning (how?), and the type(s) of knowledge exchanged and co-produced (what?). Descriptions and examples for each type

\footnotetext{
${ }^{5}$ For instance, when an academic from the Dutch part of the Euregio engages in a learning interaction with a practitioner from the Walloon part, both the territorial and role-based boundaries are crossed.
} 


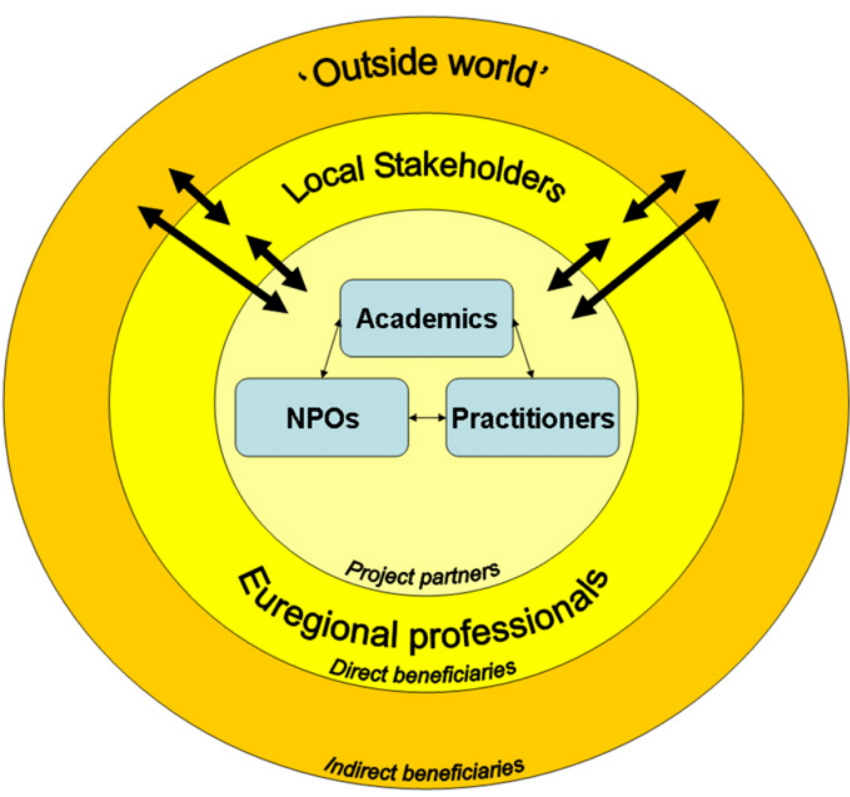

Fig. 3. The SUN learning network can be visualized as three concentric circles constituting of (1) the SUN project partners (city practitioners, non-profit organisations (NPOs), and academics), (2) local stakeholders and Euregional professionals ('direct beneficiaries') and (3) other interested parties ('indirect beneficiaries' or 'outside world'). The arrows indicate potential learning interactions.

of learning interaction are given in Sections 4.1 to 4.4 that cluster the learning interaction types according to the knowledge boundary they most apply to.

\subsection{Territorial boundaries}

Crossing territorial boundaries refers to learning interactions among stakeholders of different Euregional territories. Such interactions occurred through a variety of activities and tools depending notably on the role of the stakeholders under concern:

Academics from Liège, Hasselt, Maastricht and Aachen, for example, exchanged knowledge on the occasion of thematic meetings, project coordination meetings, benchmarking activities, and site visits, through the Learn4SUN platform that was used to facilitate discussions and collaborative work, and also through informal exchanges like specific face-to-face meetings, phone and email contacts (learning interaction No. 1 in Table 2). The object of learning was mainly technical (exchanging amongst others scientific knowledge and data about achievements of ongoing actions), but also related to innovative practices (discussing scientific evaluation methods and procedures, methods and procedures implemented in the different neighbourhoods, etc).

Practitioners of the various Euregional territories engaged in cross-boundary learning mainly at the occasion of the thematic meetings organised on a regular basis by the action leaders, and through informal exchanges and community exchanges (learning interaction No. 2 in Table 2). The thematic meetings specially intended to foster learning related to innovative practices through case stories: a practitioner tells how a problem was approached in his/her city, what were the difficulties and opportunities, what worked and what didn't, and gives his/her impressions about the whole process. Exogenous practices are also reported and their feasibility and relevance for the SUN neighbourhoods are discussed. This kind of dialogue sometimes led to the transfer of innovative practices from one territory to another. Relevant examples were the transfers of the collective purchase of housing insulation experiment and the call for collective greening projects among the different SUN partner cities.

Citizens from different territories engaged in cross-boundary learning mainly at the occasion of the community exchanges (learning interaction No. 3 in Table 2). For instance, when citizens from Liège, Verviers and Eupen visited the neighbourhood Heerlen - MSP, they had the opportunity to discuss with citizens from Heerlen, especially during the lunch that MSP inhabitants had prepared at their vegetable garden. The object of learning was mainly attitudinal, notably comparing life in Heerlen to that in other cities and reflecting on problems like litter and insecurity. Sometimes it was technical (e.g. what plants do you cultivate, and how?) and occasionally related to innovative practices (what are the greening actions realised in MSP, what was their value compared to the greening actions realised in other neighbourhoods). This relationship, however, needed to overcome the language barrier, a task which was often difficult when citizens were involved. Translators thus proved very important to support these learning interactions.

Overall, the territorial boundary did appear relatively difficult to cross. It is most pronounced when territories differ on various features (language, culture, institutional context), and is partly mitigated when a main feature between territories is shared (such as the same language between Heerlen-MSP and Genk, and the partly shared institutional context between Liège and Eupen). Also, its inhibitive character depends on the types of actors involved; for instance it appeared relatively weak for academics, but stronger for practitioners and citizens. To facilitate boundary crossing, one observes that territorial boundaries are crossed easier in the absence of other (e.g. role-based, sectoral, project) boundaries. The actors involved in the three aforementioned learning interactions work on similar issues in relation to the SUN project, to the extent that the sectoral boundary can be considered weak. In addition, they share similar roles within their respective communities and in the SUN project. Such trans-border learning interactions are thus probably best facilitated by actors having similar roles, with similar knowledge specialisations, and facing similar problems (e.g. how to stimulate renovation) in similar contexts (in the case of SUN: former industrial neighbourhoods).

\subsection{Role-based boundaries}

Crossing role-based boundaries refers to learning interactions among city practitioners, academics, NPOs, local stakeholders and Euregional professionals. In the SUN project, we observe that almost all project coordination activities required working across role-based boundaries. Especially the coordination of the neighbourhood activities (i.e. their definition, preparation and follow-up) required strong cooperation between the various project partners (academics, city practitioners, NPOs), and-in several cases-representatives of local stakeholders. The object of learning in such activities was mainly related to innovative practices: people reported about inspiring practices, about their past experiences, debated about them and looked together for more innovative practices to solve concrete problems. A representative example is learning interaction No. 4 in Table 2: the interaction between members of the so-called 'working groups' created to coordinate the Energy action in the different cities. These groups included the city practitioners, academics and NPOs involved in the SUN Energy action, and were extended with representatives of local organisations active in the energy domain (thus contributing to project boundary crossing as well). These working groups were conceived of as an open exchange platform, gathering all actors engaged in a given action theme - in this case the stimulation of the energy renovation of private housing buildings. These actors have different functions or roles in relation to this theme. For instance, some of 
Table 2

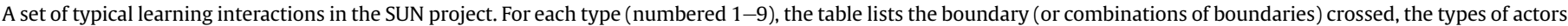

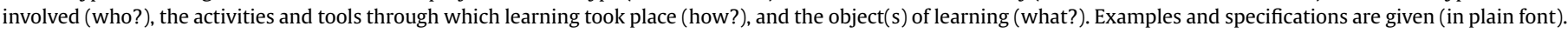
The learning interaction number is quoted as a reference in the body text.

\begin{tabular}{|c|c|c|c|c|}
\hline No. & Boundaries & Who? & How? & What? \\
\hline 1 & Territorial & Academics & $\begin{array}{l}\text { Thematic meetings, Project coordination, } \\
\text { Benchmarking activities, Site visits, } \\
\text { Learn4SUN platform (discussions on the forum, } \\
\text { collaborative work),Informal exchanges }\end{array}$ & $\begin{array}{l}\text { Technical (e.g. scientific knowledge, } \\
\text { information about ongoing SUN } \\
\text { activities), Innovative practices } \\
\text { (e.g. scientific methods and procedures; } \\
\text { methods and procedures implemented } \\
\text { on the neighbourhoods) }\end{array}$ \\
\hline 2 & Territorial & Practitioners & $\begin{array}{l}\text { Thematic meetings (organised by action leaders } \\
\text { so that practitioners could report and discuss } \\
\text { about their practices), Informal exchanges } \\
\text { Community exchanges }\end{array}$ & $\begin{array}{l}\text { Innovative practices (dialogue on, } \\
\text { e.g., collective purchase of housing } \\
\text { insulation and the call for collective } \\
\text { greening projects supports the transfer } \\
\text { of innovative practices) }\end{array}$ \\
\hline 3 & Territorial & Local stakeholders (citizens) & $\begin{array}{l}\text { Community exchanges (e.g. visit of citizens } \\
\text { from Liège, Verviers, and Eupen to the vegetable } \\
\text { garden set-up in Heerlen-MSP } \\
\text { (under the Greenery action)) }\end{array}$ & $\begin{array}{l}\text { Technical (e.g. how to cultivate vegetables?), } \\
\text { Attitudinal (reflections on life and problems } \\
\text { encountered in the different neighbourhoods), } \\
\text { Innovative practices (how do the various } \\
\text { greening actions compare?) }\end{array}$ \\
\hline 4 & Role-based, Project & $\begin{array}{l}\text { Practitioners, Academics, } \\
\text { NPOs, Local stakeholders }\end{array}$ & $\begin{array}{l}\text { Project coordination (working groups } \\
\text { to coordinate the Energy action } \\
\text { in the different neighbourhoods) }\end{array}$ & $\begin{array}{l}\text { Innovative practices (reflection } \\
\text { on innovative methods to stimulate } \\
\text { energy renovation of private buildings) }\end{array}$ \\
\hline 5 & Role-based, Project & $\begin{array}{l}\text { Academics, Practitioners, } \\
\text { Local stakeholders (citizens) }\end{array}$ & $\begin{array}{l}\text { Neighbourhood activities } \\
\text { (call for greening projects) }\end{array}$ & $\begin{array}{l}\text { Technical (gardening techniques like the } \\
\text { choice of plants), Attitudinal (awareness } \\
\text { about environmental challenges associated } \\
\text { with urban greening) }\end{array}$ \\
\hline 6 & $\begin{array}{l}\text { Role-based, Project, } \\
\text { Territorial }\end{array}$ & $\begin{array}{l}\text { NPOs, Practitioners, Academics, } \\
\text { Euregional professionals } \\
\text { (private renovation contractors) }\end{array}$ & $\begin{array}{l}\text { Neighbourhood activities } \\
\text { (collective purchase of housing } \\
\text { insulation - call for tenders } \\
\text { and related information sessions) }\end{array}$ & $\begin{array}{l}\text { Attitudinal (reflecting on the importance } \\
\text { for the construction sector to adopt } \\
\text { sustainable approaches to building } \\
\text { renovation), Innovative practices (reflecting } \\
\text { on the call for tenders as an innovative procedure) }\end{array}$ \\
\hline 7 & Role-based & $\begin{array}{l}\text { Euregional professionals } \\
\text { (private renovation contractors), } \\
\text { Local stakeholders (citizens) }\end{array}$ & $\begin{array}{l}\text { Neighbourhood activities (collective } \\
\text { purchase of housing } \\
\text { insulation - implementation } \\
\text { and related information sessions) }\end{array}$ & Technical (e.g. related to insulation techniques) \\
\hline 8 & $\begin{array}{l}\text { Sectoral, } \\
\text { Role-based, Project }\end{array}$ & $\begin{array}{l}\text { Practitioners, Academics, } \\
\text { Local stakeholders (Local } \\
\text { associations and NGOs) }\end{array}$ & $\begin{array}{l}\text { Project coordination (coordination } \\
\text { of the various SUN actions within } \\
\text { a neighbourhood, mediated } \\
\text { by a neighbourhood manager), } \\
\text { Informal exchanges }\end{array}$ & $\begin{array}{l}\text { Technical (e.g. data and knowledge about } \\
\text { the neighbourhood), Attitudinal } \\
\text { (e.g. awareness about the different } \\
\text { thematic challenges, and the way } \\
\text { they may cross-fertilize), Innovative practices: } \\
\text { (e.g. to what extent do innovative practices } \\
\text { enhance the neighbourhood?) }\end{array}$ \\
\hline 9 & $\begin{array}{l}\text { Project, Territorial, } \\
\text { Role-based }\end{array}$ & $\begin{array}{l}\text { Practioners, NPOs, Outside world } \\
\text { (Practitioners from external cities) }\end{array}$ & $\begin{array}{l}\text { Benchmarking activities } \\
\text { (e.g. identifying innovative practices } \\
\text { for economic development } \\
\text { in neighbourhoods in Brussels), } \\
\text { Site visits SUN events }\end{array}$ & $\begin{array}{l}\text { Innovative practices (identifying innovative } \\
\text { practices elsewhere, and reflecting on how } \\
\text { they may be adapted to the context of SUN) }\end{array}$ \\
\hline
\end{tabular}

them are social workers dealing with energy bills of poorest citizens, while others are advisors in information centres specialised in energy questions.

The implementation of the neighbourhood activities also implied crossing role-based boundaries, since such activities engaged various actor groups, namely city practitioners, academics, NPOs, local stakeholders (e.g. citizens, local associations, local businesses, schools) and/or Euregional professionals (e.g. renovation contractors). A representative example is the learning interaction among academics, city practitioners and citizens at the occasion of the call for greening projects organised under the SUN Greenery action in Liège and Verviers (Table 2, No. 5). The object of learning included attitudinal aspects related to the various challenges associated with urban greening (like landscape quality and image of the neighbourhood, biodiversity, water management, and sustainable development). Also, technical learning on gardening techniques occurred, for example related to the choice of the plants. Another representative example is the collective purchase of housing insulation organised under the SUN Energy action. This learning interaction among SUN partners operating in Liège (NPOs, city practitioners and academics) and private renovation contractors was facilitated by organising a call for tenders for the collective purchase of housing insulation (Table 2, No. 6). Besides conventional criteria of quality and price, this call included unconventional social criteria. Through the widely communicated call for tenders and through the information sessions organised to inform contractors, the object of learning was mainly attitudinal, addressing for instance the importance for the construction sector to evolve and promote more sustainable approaches to building renovation. It also related to innovative practices, as the call for tenders was a procedure to which most of the contractors were unfamiliar with. Through the interaction between SUN partners on the one hand, and private parties outside the SUN project on the other, this learning interaction contributed also to the project boundary crossing. Moreover, as the practice of collective purchasing was later shared with other SUN neighbourhoods (see 
also Table 2, No. 2), it contributed to territorial boundary crossing as well. In the same context, yet a different type of learning interaction occurred between private renovation contractors and local citizens through the actual implementation of the insulation works (Table 2 , No. 7). This interaction materialized through the information sessions organised by the SUN partners, at the occasion of which the preselected private contractors presented their company to local citizens, who could then decide between the different offers. During these sessions, a neutral expert was also invited to explain the technical aspects of insulation techniques.

Overall, the role-based boundary set a relatively minor barrier to learning in the context of SUN, with many fruitful learning interactions among actors of different roles. The above examples indicate that learning across role-based boundaries can be facilitated by the fact that actors having different roles either share a sectoral issue (e.g. how to stimulate the greening or energy insulation), and / or are interested in the same territory (e.g. the Hodimont neighbourhood in Verviers). However, even when an issue or territory is shared, learning across a role-based boundary is still difficult, because involved actors address the issue or the territory through different entry points, with different methods and are pursuing different ends.

\subsection{Sectoral boundaries}

Crossing sectoral boundaries refers to learning interactions among stakeholders operating within different sustainability themes, e.g. economy, greenery, energy, and social cohesion. Such interactions occurred among project partners through general project coordination activities, but most importantly through project coordination at the neighbourhood level (learning interaction No. 8 in Table 2). This local coordination was ensured by a city practitioner designated as the 'neighbourhood manager'. The neighbourhood manager organised the communication and exchange between all practitioners, academics and local stakeholders engaged in the implementation of the four SUN actions in his neighbourhood. Besides regular coordination meetings, learning interactions occurred also though various informal exchanges. In the context of this cooperation, objects of learning covered all categories to some extent. Technical objects related, e.g., to the exchange of data and knowledge about the neighbourhood, attitudinal objects related to awareness raising about the different thematic challenges, and the ways developments in energy, greening, economy and social cohesion may cross-fertilize, while objects of innovative practices included reflection on the extent to which the various innovative practices indeed contributed to an enhanced neighbourhood. In these learning interactions, rolebased and project boundaries were crossed to some extent, but they occurred mainly across the sectoral boundary: people involved in the Community action learnt from people involved in the Greenery or in the Energy actions, etc.

Overall, the sectoral boundary proved relatively significant in the context of SUN. This was partly due to the project structure, distinguishing four concrete actions, naturally creating groups of people with similar knowledge specializations. Although this structure was a vehicle for territorial boundary crossing (e.g. see Table 2, No. 6), it may have hampered sectoral boundary crossing to some extent. The rationale to overcoming the sectoral boundary is the integrated area-based approach, i.e. stimulating learning interactions through the coordination of project activities at the neighbourhood level. Although in some areas these interactions were fruitful - as in the example above-in other neighbourhoods they appeared less successful. The role of the neighbourhood manager in promoting such learning interactions is significant, but also other factors may play a role.

\subsection{Project boundaries}

Crossing project boundaries refers to (two-way) learning interactions among stakeholders inside and outside the SUN project sphere. A number of cases of project boundary crossing between project partners and direct beneficiaries are already described as part of role-based boundary crossing (Section 4.2). Here, we focus on learning interactions between the project partners and the 'outside world'.

Such interactions first occurred through the various benchmarking activities conducted by the SUN partners (mainly the academics and to a lesser extent other types of actors) mainly during the first part of the project (learning interaction No. 9 in Table 2). City practitioners were indeed expecting to be informed about inspiring innovative practices that they could apply in their neighbourhood to address the specific thematic challenges raised by the SUN project. Academics thus looked for external examples through literature review, web searches or still by consulting their professional networks. The most interesting examples were developed through case study reports and communicated to the concerned city practitioners. In this way, for example, the identification of interesting practices for economic development of neighbourhoods in Brussels inspired revitalisation actions undertaken in empty shops in Liège, Verviers and Genk. In some cases, the benchmarking activities led to the organisation of site visits allowing in-depth exchanges with hosting practitioners. Some practices were also presented at the occasion of the SUN events, and so communicated to a wider audience (the 'outside world').

Overall, the project boundary appeared relatively easy to cross. Project partners showed a clear interest in learning from practices elsewhere, and, vice-versa, 'external' practitioners were generally motivated to discuss their experiences with other parties. This highlights the added value of external sources of inspiration in order to feed local innovation processes. Learning mainly relates to innovative procedures, methods, and strategies that are transferred with a certain degree of adaptation in order to adjust to the recipient context.

\section{Discussion}

\subsection{Factors supporting the joint learning process}

Overall, the case study of the SUN project illustrates how diversity among members of a LN can contribute to a rich learning process. Different members, operating in different contexts, bring in different experiences, viewpoints, knowledge and ideas. Exchanging and co-producing knowledge is generally considered inspiring and fruitful, as illustrated by the variety of cross-boundary learning interactions described in the previous section. One of the main characteristics of the SUN-LN in support of joint learning is its action-oriented nature. The SUN actions bring various groups together in neighbourhood activities to translate the concept of sustainable development into something tangible. Learning for sustainable development then becomes concrete, fun, and in one's own interest. This observation confirms previous research, arguing that knowledge is localized, embedded, and invested in practice (Carlile, 2002) and that learning networks on urban development can only be sustained on the longer term if they are given some legitimacy to influence concrete decisions (McFarlane, 2011).

A second main factor is the broad mix of implemented activities and tools. Table 2 illustrates how different types of activities and tools support different types of learning interactions over different types of knowledge boundaries. For example, thematic meetings among city practitioners facilitated learning interactions about innovative practices across territorial boundaries. Community 
exchanges notably facilitated learning interactions among citizens from different territories (mainly attitudinal). Project coordination activities at the neighbourhood level supported learning interactions across sectoral boundaries, involving a range of objects of learning (technical, attitudinal, innovative practices). Neighbourhood activities supported learning interactions over role-based and project boundaries, and in some cases over territorial boundaries as well. Benchmarking activities, site visits, and SUN events provided the key ways of crossing project and territorial boundaries, exchanging technical knowledge and experiences with innovative practices. Finally, the Learn4SUN portal was valuable to facilitate learning interactions among academic partners operating in different Euregional territories. Adopting a broad mix of activities and tools thus contributes to a 'robust' joint learning process, with learning interactions occurring over different knowledge boundary types.

Further factors include:

- An integrated and area-based approach. Many projects indeed concentrate on a specific theme or sector, like for example 'sustainable buildings' or 'accessible green spaces'. The SUN project addresses specific neighbourhoods, in parallel to specific themes. This integrated approach contributes to learning and innovation specifically across sectoral boundaries (see also Cameron et al., 2004).

- The role of individuals in stimulating and facilitating learning interactions across specific boundaries. In the SUN project, for example, neighbourhood managers had an important role in facilitating sectoral boundary crossing by coordinating different thematic actions at the neighbourhood level. The ability of such 'boundary managers' to motivate learning interactions thus appears important for joint learning success.

- Language translation and interpretation. The SUN project provided various facilities to overcome language barriers, including translation for a number of documents and tools (e.g. the project website) and using interpreters to support direct communication between actors. Nonetheless, language differences remain problematic in regional LNs spanning different language zones, and should be carefully considered when setting up a LN.

- Sufficient common ground. Learning across boundaries appears more effective when actors at different 'sides' of a boundary have other features in common. In the SUN project we observe that territorial boundaries, for example, are crossed easier when actors have similar roles, or share a sectoral issue. Learning across boundaries may thus be more effective when boundaries are crossed 'one by one' rather than 'all at the same time'.

A main challenge the SUN project raises relates to the importance to create common learning interests among $\mathrm{LN}$ members on different 'sides' of knowledge boundaries. In the SUN project, such common interests among project partners were created largely during the project preparation phase, during which a common, overarching objective was formulated (sustainable neighbourhood development) and subsequently translated to four concrete thematic challenges and targets. In theory, an integrating concept like sustainable urban neighbourhood development has the capacity to bridge boundaries as a fundamental overarching theme to which all LN members aim to contribute. In our experience, however, this overarching objective was considered rather abstract, notably among citizens and practitioners. As such, it did not develop (nor was it pursued by the project team) as a main driver of cross-boundary learning in the context of SUN. Much stronger drivers of learning were the more practical challenges and targets formulated on the neighbourhood level, and for each thematic action. The drawback of such concrete challenges and targets, however, is that they lack 'integrating power' especially across sectors and territories. A possible way ahead is thus to develop and test boundary objects (Carlile, 2002; Star and Griesemer, 1989) that connect integrative concepts with a very practical focus on neighbourhood development. Initiatives like developing a common vision on what a sustainable urban neighbourhood entails (Beumer et al., 2010), and monitoring quality-of life in neighbourhoods (Oldenhuizing et al., 2013) are promising in this respect.

\subsection{Approach for analysing the joint learning process}

The analytical framework developed and applied in this article aims to support the systematic analysis of learning processes in regional LNs for sustainable development. Concretely, it allows creating a systematic overview of learning interactions in a complex regional $\mathrm{LN}$ like the SUN project. To this end, the framework links categories of involved actors (who learns?), activities and tools (learns how?), and learning objects (learns what?) to main knowledge boundaries in the LN.

Although tailored to the context of the SUN project, we expect the framework to be applicable to other regional LNs for sustainable development as well. Naturally, appropriate classifications-for actors, activities and tools, learning objects, and knowledge boundaries-will depend to some extent on the precise focus of the LN. Yet, the classifications used in our analysis have generic value and can be used as a template. The three categories of learning objects (technical, attitudinal, innovative practices), for example, are based on established learning classifications identified through literature review. They proved suitable to describe the various learning objects exchanged and co-produced under the SUN project, and are probably applicable to other processes of collective innovation. Also, knowledge boundaries like the role-based and sectoral boundary are inherent to regional LNs focussing on sustainable development that will generally involve a diverse group of actors operating under different (social, environmental, economical) themes. Considering the increasing importance of European cross-border cooperation, ${ }^{2}$ as well as emerging research on global LNs for sustainable development (Van Ginkel, 2006), we also expect the territorial boundary to prove significant for various current and future LNs.

Applying the analytical framework may provide added value on a number of accounts. First, it supports creating an overview of learning interactions across knowledge boundaries. As illustrated in this article, this allows for a first analysis of factors supporting cross-boundary learning, and delivers first insights in the relative significance of different knowledge boundary types. Second, it thereby provides a basis for the selection of case studies to explore learning processes in depth. In the SUN project, for example, in depth analyses of specific learning processes are carried out through interviews and questionnaires as part of the overall evaluation and monitoring process. Finally, the framework has potential to support the design of regional LNs for sustainable development, as a reflective tool for choosing appropriate activities and tools to support learning across different knowledge boundary types. As such, it may be of value to academics, governments, or other actor with an interest in initiating such LNs. However, to become a robust and practical tool, the analytical framework should be further tested and developed in other learning contexts.

A main methodological challenge the SUN project raises is monitoring and communicating learning outcomes through a participatory 'bottom-up' approach. Given the complexity of the SUN project, and the sheer amount of neighbourhood and other learning activities taking place, it is hard for any individual to 
engage in, or even to keep track of, all learning processes. Moreover, learning processes are often of informal character, and thereby inherently difficult to identify. This situation highlights the importance of continuous communication by LN members about learning activities taking place, to capture and store knowledge exchanged and co-produced, and to make that knowledge available to a wider audience. Such communication, however, is not easy to achieve, as it requires commitment from LN members (who may prioritise their practical activities over monitoring and communication activities) and possibly overcoming language differences. The methodological challenge is thus to set-up participatory, bottom-up monitoring activities that work. Tailor made web 2.0 social networks (De Kraker et al., 2013) could facilitate such monitoring activities by providing a low threshold, dynamic communication environment, and are worth testing in this respect.

\section{Conclusions}

In this paper, we analysed learning interactions within the SUN project, as a case study of a regional learning network on sustainable urban development. To this end, we developed an analytical framework linking categories of involved actors, project activities and tools, and learning objects to main knowledge boundaries in the LN. The framework proved useful to characterise a set of typical learning interactions identified by the SUN academic partners through their day-to-day observation of the SUN project.

Our analysis highlights a number of factors that support such learning interactions in regional LNs for sustainable development. The action-oriented nature of the LN and the mix of activities and tools were considered as the main ones. To support joint learning processes further, our analysis highlights the need for boundary objects that connect overarching, integrating concepts like 'sustainable development' or 'quality of life' to concrete problems and tasks experienced at the local level.

The developed analytical framework, we argue, has generic applicability, although the identified categories need to be tailored to the specific joint learning context at hand. It can be further used in the analysis and design of joint learning processes in complex networks and needs further testing in this respect. To further advance the analysis of joint learning processes, participatory 'bottom-up' approaches for monitoring learning processes are promising to capture and disseminate learning outcomes in a direct and interactive way.

\section{Acknowledgements}

This research is part of the SUN project funded by the Interreg IVa programme in the Euregio Meuse-Rhine. We thank our project partners and all others involved in the SUN project for the fruitful collaboration. We also thank our colleagues from the 3-LENSUS project for stimulating discussions on the topic of learning, and the anonymous reviewers for their recommendations for improving the text.

\section{References}

Armitage, D., Marschke, M., Plummer, R., 2008. Adaptive co-management and the paradox of learning. Global Environ. Change 18, 86-98.

Baeten, G., Swyngedouw, E., Albrechts, L., 1998. Politics, institutions and regional restructuring processes: from managed growth to planned fragmentation in the reconversion of Belgium's last coal mining region. Reg. Stud. 33, 247-258.

Barton, A., Dlouhá, J., 2011. In: Multi-Actor Learning for Sustainable Regional Development in Europe: A Handbook of Best Practice. Grosvenor House Publishing Limited, Surrey, UK.

Bennett, C., Howlett, M., 1992. The lessons of learning: reconciling theories of policy learning and policy change. Policy Sci. 25, 275-294.

Bessant, J., Tsekouras, G., 2001. Developing learning networks. AI \& Soc. 15, 82-98.
Beumer, C., Valkering, P., Ruelle, C., 2010. Envisioning a Sustainable Urban Neighbourhood. SUN Action 2 Position Paper, March 2010. Maastricht University ICIS, Maastricht, The Netherlands.

Cameron, J., Odendaal, N., Todes, A., 2004. Integrated area development projects: working towards innovation and sustainability. Urban Forum 15, 311-339.

Cardoso, I.M., Guijt, I., Franco, F.S., Carvalho, A.F., Neto, P.S.F., 2001. Continual learning for agroforestry system design: university, NGO and farmer partnership in Minas Gerais, Brazil. Agric. Syst. 69, 235-257.

Carlile, P.R., 2002. A pragmatic view of knowledge and boundaries: boundary objects in new product development. Organ. Sci. 13, 442-455.

Carlile, P.R., 2004. Transferring, translating, and transforming: an integrative framework for managing knowledge across boundaries. Organ. Sci. 15, 555568.

Colardyn, D., Bjornavold, J., 2004. Validation of formal, non-formal and informal learning: policy and practices in EU Member States. Eur. J. Educ. 39, 69-89.

Cooke, P., Uranga, M.G., Etxebarria, G., 1997. Regional innovation systems: institutional and organisational dimensions. Res. Policy 26, 475-491.

Craps, M., 2003. Social Learning in River Basin Management. HarmoniCOP WP2 reference document. Catholic University of Leuven, Centre for Organizational and Personnel Psychology, Leuven, Belgium.

De Kraker, J., Cörvers, R., Valkering, P., Hermans, M., Rikers, J., 2013. Learning for sustainable regional development: towards learning networks 2.0? J. Cleaner Prod. 49, 114-122.

Dewulf, C., 2003. Op Hete Kolen: De Beloftes voor 2030. Parkstad Limburg, Heerlen, The Netherlands.

Downes, S., 2007. Learning networks in practice. In: Ley, D. (Ed.), Emerging Technologies for Learning. BECTA, London, pp. 19-27.

Edquist, C. (Ed.), 1997. Systems of Innovation. Technologies, Institutions and Organizations. Pinter, London.

Fraser, C., Marechal, L., 2003. Belgium: the Case of Wallonia. In: Couch, C., Fraser, C., Percy, S. (Eds.), Urban Regeneration in Europe. Blackwell Science, Oxford, UK, pp. 126-134.

Haug, C., Huitema, D., Wenzler, I., 2011. Learning through games? Evaluating the learning effect of a policy exercise on European climate policy. Technol. Forecast. Soc. Change 78, 968-981.

Heerlen, 2008. Stadsvisie Heerlen 2026: Energiek Hart van Parkstad. Heerlen, The Netherlands.

Hegger, D., Lamers, M., Zeijl-Rozema, A.V., Dieperink, C., 2012. Conceptualising joint knowledge production in regional climate change adaptation projects: success conditions and levers for action. Environ. Sci. Pol. 18, 52-65.

Holden, M., 2008. Social learning in planning: Seattle's sustainable development codebooks. Prog. Plan. 69, 1-40.

Jochem, E., Gruber, E., 2007. Local learning-networks on energy efficiency in industry - successful initiative in Germany. Appl. Energy 84, 806-816.

Lundvall, B.-Å (Ed.), 1992. National Systems of Innovation: Towards a Theory of Innovation and Interactive Learning. Pinter Publishers, London.

Manring, S.L., 2007. Creating and managing interorganizational learning networks to achieve sustainable ecosystem management. Organ. Environ. 20, 325-346.

Manring, S.L., Moore, S.B., 2006. Creating and managing a virtual interorganizational learning network for greener production: a conceptual model and case study. J. Cleaner Prod. 14, 891-899.

McFarlane, C., 2011. Learning the City: Knowledge and Translocal Assemblage. Wiley-Blackwell, Hoboken, New Jersey.

Oldenhuizing, J., Dekraker, J., Valkering, P., 2013. Design of a Quality-of-Life monitor to promote learning in a multiactor network for sustainable urban development. J. Cleaner Prod. 49, 74-84.

Pahl-Wostl, C., Craps, M., Dewulf, A., Mostert, E., Tabara, D., Taillieu, T., 2007. Social learning and water resources management. Ecol. Soc. 12, 5 [online] Available at: http://www.ecologyandsociety.org/vol12/iss2/art5/.

Pasmans, P., Voorburg, A., 2005. Buurt in Balans: Sociale Buurtvisie voor Meezenbroek, Schaesbergerveld en Palemig. NovioConsult Van Spaendonck BV, Nijmegen, The Netherlands.

Roome, N., 2001. Conceptualizing and studying the contribution of networks in environmental management and sustainable development. Bus. Strategy Environ. 10, 69-76.

Schartinger, D., Rammera, C., Fischer, M.M., Fröhlich, J., 2002. Knowledge interactions between universities and industry in Austria: sectoral patterns and determinants. Res. Pol. 31, 303-328.

Star, S.L., Griesemer, J.R., 1989. Institutional ecology, 'translations' and boundary objects: amateurs and professionals in Berkeley's Museum of Vertebrate Zoology, 1907-39. Soc. Stud. Sci. 19, 387-420.

Van de Kerkhof, M., Wieczorek, A., 2005. Learning and stakeholder participation in transition processes towards sustainability: methodological considerations. Technol. Forecast. Soc. Change 72, 733-747.

Van Ginkel, H., 2006. Sharing knowledge: roles of e-learning in creating the global learning space. Int. Arch. Photogram. Remote Sens. Spat. Info. Sci. XXXVI (6), 1-2.

Veldkamp, A., Van Altvorst, A.C., Eweg, R., Jacobsen, E., Van Kleef, A., Van Latesteijn, H., Mager, S., Mommaas, H., Smeets, P.J.A.M., Spaans, L., Van Trijp, J.C.M., 2009 Triggering transitions towards sustainable development of the Dutch agricultural sector: TransForum's approach. Agron. Sustain. Dev. 29, 87-96.

Von Malmborg, F., 2007. Stimulating learning and innovation in networks for sustainable regional development: the role of local authorities. J. Cleaner Prod. $15,1730-1741$.

Wenger, E., 1998. Communities of Practice: Learning, Meaning and Identity. Cambridge University Press, Cambridge, UK. 